\title{
Target proteins reprogrammed by As and As + Si treatments in Solanum lycopersicum L. fruit
}

Marta Marmiroli ${ }^{1 *}$, Francesca Mussi ${ }^{1}$, Davide Imperiale ${ }^{1}$ and Nelson Marmiroli ${ }^{1,2}$

\begin{abstract}
Background: Arsenic is an important contaminant of many arable soils worldwide, while silicon, one of the most abundant elements in the earth's crust, interacts with As in the context of plant metabolism. As toxicity results largely from its stimulation of reactive oxygen species, and it is believed that Si can mitigate this process through reduction of the level of oxidative stress. Experiments targeting the proteomic impact of exposure to As and $\mathrm{Si}$ have to date largely focused on analyses of root, shoot and seed of a range of mainly non-solanaceous species, thus it remains unclear whether oxidative stress is the most important manifestation of As toxicity in Solanum lycopersicum fruit which during ripening go through drastic physiological and molecular readjustments. The role of Si also needs to be re-evaluated.

Results: A comparison was drawn between the proteomic responses to As and As + Si treatments of the fruit of two tomato cultivars (cvs. Aragon and Gladis) known to contrast for their ability to take up these elements and to translocate them into fruits. Treatments were applied at the beginning of the red ripening stage, and the fruit proteomes were captured after a 14 day period of exposure. For each cultivar, a set of differentially abundant fruit proteins (from non-treated and treated plants) were isolated by 2DGE and identified using mass spectrometry. In the fruit of $\mathrm{cv}$. Aragon, the As treatment reprogrammed proteins largely involved in transcription regulation (growth- regulating factor 9-like), and cell structure (actin-51), while in the cv. Gladis, the majority of differentially expressed proteins were associated with protein ubiquitination and proteolysis (E3 ubiquitin protein, and hormones (1-aminocyclopropane 1-carboxylase).

Conclusions: The present experiments were intended to establish whether Si supplementation can be used to reverse the proteomic disturbance induced by the As treatment; this reprogram was only partial and more effective in the fruit of $\mathrm{cv}$. Gladis than in that of cv. Aragon. Proteins responsible for the protection of the fruits' quality in the face of As-induced stress were identified. Moreover, supplementation with Si seemed to limit to a degree the accumulation of As in the tomato fruit of cv. Aragon.
\end{abstract}

Keywords: Proteomics, Oxidative stress, Fruit development, Environmental toxin, Beneficial element

\section{Background}

The important crop plant tomato has also been adopted as the leading genetic model for solanaceous species $[1,2]$. Over 75,000 accessions are maintained by various gene banks, and some 7000 cultivars are grown commercially around the world [3]. Two independent versions of the species' genomic DNA sequence have been acquired (one

\footnotetext{
* Correspondence: marta.marmiroli@unipr.it

1 Department of Chemistry, Life Sciences and Environmental Sustainability,

University of Parma, Parco Area delle Scienze 33/A, 43124 Parma, Italy

Full list of author information is available at the end of the article
}

from the inbred cultivar Heinz 1706 and the other from the close wild relative Solanum pimpinellifolium LA1589, http://solgenomics.net/).

The development of the tomato fruit proceeds through several major stages [4]: the early phase is characterized by rapid cell division, growth and endoreduplication [5], the mature green stage by extensive metabolic reorganization [6] and the final stages by the conversion of chloroplasts into chromoplasts, the accumulation of carotenoids and the degradation of chlorophyll $[7,8]$. At the onset of the red ripening stage, starch is metabolized 
into glucose, fructose and various organic acids [2]. A proteomic scan of the fruit of eight tomato cultivars has defined over 1200 gel features, of which around a third varied in intensity during the ripening stage, while a comparison between six cultivars at the cell expansion and orange-red stages revealed over 1000 features [9, 10]. The chloroplast-to-chromoplast transition similarly involves large numbers of proteins [11].

Arsenic in the environment is of geochemical and anthropic origin, in the Earth's crust, total As is estimated to be $4.01 \times 10^{16} \mathrm{~kg}$ [12]. $1.715 \times 10^{7} \mathrm{~kg} /$ year of As is released from lithosphere through terrestrial volcanic exhalations and eruptions. Industry, mining and agriculture release into the environment $80 \mathrm{Mt}$./year of As [13]. The As contaminates water bodies, drinking water, and contributes to crop contamination through irrigation [12, 14]. Fertilizers and pesticides release As in agricultural soil where some crop species, such as rice and other vegetables may take up and translocate As in their edible parts $[15,16]$.

Excessive levels of arsenic (As) can be toxic to many plant species: its presence induces oxidative stress, suppresses photosynthesis and disrupts metabolism by replacing the phosphate in ATP with the unstable form ADP-As [17-19]. While silicon ( $\mathrm{Si}$ ) is not generally considered to be essential for plant growth and development, its presence does reduce the uptake and root-to-shoot transport of certain heavy metal ions and metalloids, including As [20-22]. It is believed that Si application can reduce the level of oxidative stress experienced in plant tissue by bearing down on the production of reactive oxygen species (ROS), by enhancing the activity of various antioxidants, by adjusting the osmotic potential of the cell and by increasing photosynthetic activity [23-25]. The effect of both exogenously supplied $\mathrm{As}$ and $\mathrm{Si}$ on the plant proteome has been documented in several species $[26,27]$. In rice, a strong interaction between the two elements has been demonstrated [23, 28, 29]. The growth and development of the tomato is strongly affected by both elements: for example, $\mathrm{Si}$ influences the amount of As translocated to the tomato shoot in a cultivar-dependent fashion [30-32]. To date, their proteomic effect in tomato has been determined in the root and shoot [33-35], but not as yet in the fruit. In a comparison drawn between the two rather closely related cultivars Aragon and Gladis, Marmiroli et al. [31] were able to demonstrate differences in the amount of As reaching the fruit following exposure of the plant to either As on its own or in combination with $\mathrm{Si}$.

Fruit provides humans with a source of nutritional elements and beneficial molecules, in particular tomato berry constitutes one of the main staples of the healthy "Mediterranean diet" [36]. Since the early domestication, tomato plants have been selected for useful traits, among which increase in fruit size and, more recently, fruit shape variety and high sugars content [1].

All fruit metabolism is organized in networks in which proteins such as enzymes, transcription factors, and transporters play a crucial role. When the ripening process evolves in time, as well as in response to environmental stimuli this networking is reprogrammed [37-39].

Therefore environmental cues interact with the genotype causing alterations in fruit enzymes pool ultimately leading to conspicuous changes in fruit metabolites and organoleptic characteristics $[37,40,41]$.

The purpose of the present experiments was to characterize the effect on the fruit proteome of exposure to $\mathrm{As}$ and $\mathrm{As}+\mathrm{Si}$ in genetically similar, but materially different with respect to their response to these treatments, in particular, to the extent to which they accumulate As in their fruit [31].

The fruit proteome of the two cultivars responded to the As and As + Si treatments in distinct ways: in cv. Aragon fruit, Si exerted a more effective protection than in the fruit of cv. Gladis. Indeed in fruits treated with the As and $\mathrm{As}+\mathrm{Si}$ the proteome reprogramming resulted in part overlapped with changes associated with the ripening process.

\section{Methods}

\section{Reagents and standards}

All reagents and standards were purchased from SigmaAldrich (St. Louis, MO, USA) unless stated otherwise.

\section{Plants growth conditions}

The soil was a mixture of $20 \%$ silica, $40 \%$ sphagnum moss peat (Presto Durpes UAB, Vilnius, Lithuania) and $40 \%$ black peat and wood fiber (Ecomix, Vialca S.R.L., Uzzano, Italy), which was passed through a $5 \mathrm{~mm}$ sieve, sterilized by baking at $120{ }^{\circ} \mathrm{C}$ for $1 \mathrm{~h}$, then held at $50{ }^{\circ} \mathrm{C}$ for around $72 \mathrm{~h}$ until a constant weight had been attained. Seedlings of cvs Aragon and Gladis were raised for 4 weeks under a $14 \mathrm{~h}$ photoperiod provided by $300 \mu \mathrm{mol} \mathrm{m}{ }^{-2} \mathrm{~s}^{-1}$ metal halide lamps in cabinets providing a $23 / 16{ }^{\circ} \mathrm{C}$ day/night temperature regime and a relative humidity of $50 \%$. They were then transplanted in $9 \mathrm{~L}$ pots and irrigated with $500 \mathrm{~mL}$ tap water $(\mathrm{pH} 7.5$, EC 0.6-0.7 dS $\mathrm{m}^{-1}$ ) every 2 days. The soils' electrical conductivity (EC) and $\mathrm{pH}$ were monitored following the EPA methods 9045D and 9050A. Once a week, each pot was fertilized by adding $200 \mathrm{~mL}$ of $2 \% w / v$ blood meal (Guaber S.R.L., Bologna, Italy). The plants were raised in a greenhouse providing a day/night temperature of 25$30 / 13-16{ }^{\circ} \mathrm{C}$, with the natural light supplemented by $14 \mathrm{~h}$ per day of $300 \mu \mathrm{mol} \mathrm{m}^{-2} \mathrm{~s}^{-1}$ light provided by metal halide lamps. Throughout the experiment, the soils' $\mathrm{pH}$ varied in the range 6.3-6.7, while their electrical con-

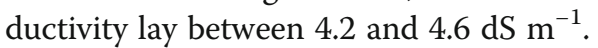




\section{Experimental design and treatments}

The As and As + Si treatments were initiated during the ripening of the first fruit (about 100 days after sowing). For the As treatment, each pot was watered with $2 \mathrm{~L}$ of $5 \mathrm{mg} \mathrm{L}^{-1} \mathrm{NaAsO}_{2}$, for the As + Si treatment, $2 \mathrm{~L}$ of $5 \mathrm{mg}$ $\mathrm{L}^{-1} \mathrm{NaAsO}_{2}$ combined with $2 \mathrm{mg} \mathrm{L}^{-1} \mathrm{CaSiO}_{3}$, while a set of control plants (nt) received neither supplement. The fruit was sampled both before the treatments commenced (t0) and 14 days later (t14d), selecting fruit of a comparable size and developmental stage, according to days after flower anthesis and color, were harvested [42].

Treatments concentrations and time were chosen according to previous work by the Authors [31] and other literature on tomato fruit proteomics $[9,43]$.

All sampled fruits were positioned between 6th and 8th leaf nodes. Each cultivar/treatment type/sampling time combination was represented by four plants, with at least three fruits per treatment taken for analysis. After harvest, the fruits were rinsed in deionized water and the replicates combined into single samples; pericarp and cuticle tissue was retained, while the placenta and seeds were discarded. The samples were snap frozen in liquid nitrogen and stored at $-80{ }^{\circ} \mathrm{C}$ until use.

\section{Determination of As content}

To measure the As content of the fruit samples, a $300 \mathrm{mg}$ aliquot of powdered material was digested in $15 \mathrm{~mL} 14.6 \mathrm{M} \mathrm{HNO}_{3}$ for $60 \mathrm{~min}$ at $165{ }^{\circ} \mathrm{C}$ following Marmiroli et al. [31]. The resulting solution was subsequently diluted to $6.7 \mathrm{M} \mathrm{HNO}_{3}$ using distilled water. The absorbance of each sample was read using an AA240FS device (Agilent Technologies, Santa Clara, CA, USA) equipped with a Varian VGA 77 vapor generator assembly. The absorbance, captured at $189 \mathrm{~nm}$, was converted into an As concentration based on a standard curve generated from a serial dilution of a 10,000 ppm standard solution. All analyses were performed in triplicate. The As concentration of the soil, tap water and blood meal, measured in the same way, lay consistently below the detection limit (BDL), defined as $0.001 \mu \mathrm{g} \mathrm{g}^{-1}$.

\section{Determination of Si content}

Inductively coupled plasma optical emission spectrometry was employed to determine the fruits' $\mathrm{Si}$ content following van der Vorm [44]. Fruits were dried, powdered, and a $300 \mathrm{mg}$ aliquot of the powdered fruit material was ashed by holding at $550{ }^{\circ} \mathrm{C}$ for $3 \mathrm{~h}$, and the ash suspended in $12.5 \mathrm{~mL} 0.08 \mathrm{M} \mathrm{H}_{2} \mathrm{SO}_{4}$ (Carlo Erba, Milan, Italy) plus $0.5 \mathrm{~mL} 23 \mathrm{M} \mathrm{HF}$ (Acros Organics, Geel, Belgium). The resulting suspension was shaken for $1 \mathrm{~h}$, then held overnight. The supernatant was assayed using an Optima 7300 DV device (Perkin Elmer, Waltham, MA, USA). The instrument parameters were set as: power $1.4 \mathrm{~kW}$; plasma gas flow rate $15 \mathrm{~L} \mathrm{~min}^{-1}$; nebulizer gas flow rate $0.78 \mathrm{~L} \mathrm{~min}^{-1}$; auxiliary gas flow rate $0.2 \mathrm{~L} \mathrm{~min}^{-1}$; sample flow rate $0.85 \mathrm{~mL} \mathrm{~min}^{-1} ; \mathrm{Si}$ wavelength $251.619 \mathrm{~nm}$ and $212.422 \mathrm{~nm}$. A calibration curve was prepared from a standard solution to convert absorbances into $\mathrm{Si}$ concentrations. All analyses were performed in triplicate.

\section{Statistics analysis of As and Si data}

After checking for normality and variance homogeneity in the dataset, three-ways analysis of variance (ANOVA), followed by one-way ANOVAs were applied to As and $\mathrm{Si}$ concentrations in fruits, with Confidence Interval (C.I.) of $=95 \%$, and statistical differences between means were deduced using Tukey's SHD post hoc test, applying a threshold of 0.005. SPSS v23 software (http:// www.ibm.com/analytics/us/en/technology/spss/) was used for all analyses.

\section{Protein extraction, quantification and separation}

Proteins were extracted using the phenol buffer-based method described by Faurobert et al. [9]: frozen fruits were ground to powder in liquid nitrogen and a $2 \mathrm{~g}$ aliquot suspended in $6 \mathrm{~mL} 700 \mathrm{mM}$ sucrose, $500 \mathrm{mM}$ Tris- $\mathrm{HCl}$ (pH 7.5), $50 \mathrm{mM}$ EDTA, $100 \mathrm{mM} \mathrm{KCl}, 2 \%(w /$ v) DTT, $0.1 \%(v / v)$ protease inhibitor cocktail, vortexed and held on ice for $10 \mathrm{~min}$. An equal volume of $500 \mathrm{mM}$ Tris- $\mathrm{HCl}$ buffered phenol was then added, the solution mixed for $10 \mathrm{~min}$ at room temperature and then centrifuged $\left(5500 \mathrm{~g}, 4{ }^{\circ} \mathrm{C}, 10 \mathrm{~min}\right)$. The phenolic phase was collected and re-extracted with $3 \mathrm{~mL}$ of the same extraction buffer. Proteins were precipitated from the pooled phenolic extract by holding overnight at $-20{ }^{\circ} \mathrm{C}$ after the addition of five volumes of $0.1 \mathrm{M}$ ammonium acetate (J.T. Baker, Deventer, Holland) saturated in methanol. The proteins were pelleted by centrifugation $\left(5500 \mathrm{~g}, 4^{\circ}\right.$ C, $30 \mathrm{~min}$ ), and washed first with cold methanol then with cold acetone. Between and after the washing steps, the proteins were re-pelleted by centrifugation $(5500 \mathrm{~g}$, $4{ }^{\circ} \mathrm{C}, 30 \mathrm{~min}$ ), and were finally dried under vacuum. For their quantification, the final protein pellet was dissolved in $200 \mu \mathrm{L}$ IEF buffer (9 M urea, 4\% (w/v) 3-[(3-cholamidopropyl)dimethylammonio]-1-propanesulfonate), $50 \mathrm{mM}$ DTT, $0.001 \%(\mathrm{v} / \mathrm{v})$ protease inhibitor cocktail, $1 \%(\mathrm{v} / \mathrm{v}) \mathrm{pH}$ 3-10 carrier ampholyte mixture) (BioRad), then assayed using a modified Bradford assay [45], taking bovine serum albumin as the standard. The proteins were resolved by two dimensional gel electrophoresis (2DE). For the first dimension $600 \mu \mathrm{g}$ of the extracted protein was loaded onto a ReadyStrip pH 4-7 $11 \mathrm{~cm}$ IPG strip (BioRad) which had been rehydrated overnight with $200 \mu \mathrm{L}$ IEF buffer containing the sample. The IEF step was based on the PROTEAN ${ }^{\bullet}$ i1 $^{\text {mi }}$ System: the voltage was limited to $250 \mathrm{~V}$ for the first $1 \mathrm{~h}$, then raised to 8 KV until $35 \mathrm{KVh}$ had elapsed. The strips were then 
bathed for $15 \mathrm{~min}$ in $3 \mathrm{~mL} 2 \% \mathrm{w} / v \mathrm{DTT}, 6 \mathrm{M}$ urea, $0.375 \mathrm{M}$ Tris- $\mathrm{HCl}$ (pH 8.8), $20 \% \mathrm{w} / \mathrm{v}$ glycerol and $2 \% \mathrm{w} /$ $\mathrm{v}$ SDS, followed by a $15 \mathrm{~min}$ incubation in $3 \mathrm{~mL} 2.5 \% \mathrm{w} /$ $\mathrm{v}$ iodoacetamide, $6 \mathrm{M}$ urea, $0.375 \mathrm{M}$ Tris- $\mathrm{HCl}(\mathrm{pH} 8.8)$, $2 \% \mathrm{w} / \mathrm{v}$ glycerol. The second dimension separation (SDS-PAGE) used a $12 \%$ Criterion $\mathrm{XT}^{\mathrm{TM}}$ Bis-Tris gel set in a Criterion ${ }^{\text {тм }}$ Dodeca $^{\text {тм }}$ cell (BioRad); the electrolyte used was 1 M 3-(N-morpholino)propanesulfonic acid, $1 \mathrm{M}$ Tris, $20 \mathrm{mM}$ EDTA, 2\% w/v SDS. The gels were stained in QC Colloidal Coomassie G-250 (BioRad). Each assay included three biological replicates, each of which represented three fruits of equivalent ripening stage, harvested from three different plants.

\section{Spot (feature) analysis}

2DE gel images were scanned using the ChemidocMP Imaging System (BioRad) and the images were processed and analyzed using PDQuest v8.0.1 software (BioRad) and checked manually. Feature densities were normalized via a localized regression method and subsequently against the whole gel density. Features were fully analyzed only when detected in all three replicates gels. The density of each feature was averaged over the three replicates and a Student's $t$ test analysis performed applying a threshold of 0.05 to test for significance in abundance between the three treatments ( $\mathrm{nt}$, As and $\mathrm{As}+\mathrm{Si}$; see Additional file 1: Figure S1A, B). Gel portions containing selected features were excised from the gel using an EXQuest Spot Cutter (BioRad), destained by soaking for $30 \mathrm{~min}$ in a $1: 1$ solution of $100 \mathrm{mM}$ ammonium bicarbonate and acetonitrile (J.T. Baker, Deventer, Holland) and digested with trypsin following the Shevchenko et al. [46] protocol.

\section{Protein identification}

Tryptic peptides were desalted and concentrated by passing through a Zip-Tip C18 (Millipore Corporation, Billerica, MA, USA), according to the manufacturer's protocol, then dispersed into an $\alpha$-cyano-4-hydroxycinnamic acid (4-HCCA) matrix, prepared by dissolving 4HCCA in 50\% acetonitrile/0.05\% trifluoroacetic acid and spotted on a MALDI plate. The samples were subjected to analysis by a model 4800 MALDI-TOF/TOF ${ }^{\text {тм }}$ MS analyzer (Applied Biosystems, Foster City, CA, USA). Peptide mass spectra were acquired in reflectron mode (500-4000 $\mathrm{m} / \mathrm{z}$ range) and analyzed with the help of mMass v5.5 open source software (http://www.mmass.org/). For each feature, a peak list was created and then manually checked for the presence of signal from the matrix complex, trypsin and human keratin peptides. The identification parameters were: trypsin digest: one missed cleavage, mass type: monoisotopic, peptide tolerance: $100 \mathrm{ppm}$, cysteine carbamidomethylation (fixed) and methionine oxidation (variable modification).
Peptide mass fingerprinting analysis was carried out using Mascot v2.3 and 2.4 software (http://www.matrixscience.$\mathrm{com} /$ ), and proteins identified by means of a search of the non-redundant Viridiplantae protein set within the UniProtKB-Swissprot (version 2015_04x to 2015_12) and Plant EST (version Plants_EST EST_123) (http://www.uniprot.org/) databases. Details regarding protein identification and abundance are given in Table 1, Additional file 2: Table S1 and Additional file 3: Table S2.

\section{Data mining and analysis}

Heat maps of selected proteins were generated by $\mathrm{R}$ v3.3.1 (www.r-project.org).

In modern plant biology, the most widely used ontologies are the Gene Ontology (GO) and Gene Ontology MapMan [47].

MapMan Ontology was performed using the GoMapMan tool [47] based on ITAG Release 2.3 (2011-04-26) of the tomato genome sequence (solgenomics.net/organism/ Solanum_lycopersicum/genome). MapMan 3.6.0RC1 software (mapman.gabipd.org/web/guest/mapman-download) was used to place proteins within a likely pathway.

\section{Results}

\section{The As and Si content of tomato fruit}

Arsenic concentrations detected in fruits were in accordance to the literature, even allowing for variability among cultivars [48-50]. Also Si concentrations, though seldom measured within tomato fruit, were in keeping with the literature $[51,52]$.

Table 1 The As and Si content of cv. Aragon and cv. Gladis fruits

\begin{tabular}{|c|c|c|c|c|c|c|}
\hline \multirow[b]{2}{*}{ Aragon } & \multirow[b]{2}{*}{ NT } & \multirow[b]{2}{*}{ t0 } & \multicolumn{2}{|c|}{$\begin{array}{l}\text { As } \\
\left(\mu \mathrm{g} \mathrm{g}^{-1} \mathrm{dw}\right) \\
\text { mean S.E. }\end{array}$} & \multicolumn{2}{|c|}{$\begin{array}{l}\text { Si } \\
\left(\mu g g^{-1} d w\right) \\
\text { mean S.E. }\end{array}$} \\
\hline & & & $0.00^{a}$ & 0.00 & $98.60^{a}$ & 4.21 \\
\hline & & $\mathrm{t} 14 \mathrm{~d}$ & $0.00^{a}$ & 0.00 & $78.95^{c}$ & 2.76 \\
\hline & As & to & $0.00^{a}$ & 0.00 & $98.60^{a}$ & 4.21 \\
\hline & & $\mathrm{t} 14 \mathrm{~d}$ & $1.80^{\mathrm{b}}$ & 0.06 & $82.35^{b c}$ & 0.21 \\
\hline & $\mathrm{As}+\mathrm{Si}$ & to & $0.00^{a}$ & 0.00 & $98.60^{a}$ & 4.21 \\
\hline & & $\mathrm{t} 14 \mathrm{~d}$ & $1.36^{c}$ & 0.04 & $86.40^{b c}$ & 1.56 \\
\hline \multirow[t]{6}{*}{ Gladis } & NT & to & $0.00^{a}$ & 0.00 & $94.10^{\mathrm{a}}$ & 2.85 \\
\hline & & $\mathrm{t} 14 \mathrm{~d}$ & $0.00^{a}$ & 0.00 & $72.95^{b}$ & 0.49 \\
\hline & As & to & $0.00^{a}$ & 0.00 & $94.10^{a}$ & 2.85 \\
\hline & & $\mathrm{t} 14 \mathrm{~d}$ & $0.10^{\mathrm{b}}$ & 0.04 & $75.85^{b}$ & 2.33 \\
\hline & $\mathrm{As}+\mathrm{Si}$ & to & $0.00^{a}$ & 0.00 & $94.10^{\mathrm{a}}$ & 2.85 \\
\hline & & $\mathrm{t} 14 \mathrm{~d}$ & $0.68^{c}$ & 0.06 & $85.55^{c}$ & 0.07 \\
\hline
\end{tabular}

Elements concentrations prior to the treatment (t0) and after 14 days of exposure to either the As or the As + Si treatment (t14d). Values shown in the form mean \pm S.E. $(n=3)$. Values equal to 0 means BDL. Different superscript letters (a through $\mathrm{c}$ ) within a column identify means differing significantly from one another $(p \leq 0.05)$ 
The As content of cv. Aragon fruits harvested from plants subjected to the As $+\mathrm{Si}$ treatment was significantly lower than that of fruits harvested from plants subjected to the As treatment, but the opposite was the case for $\mathrm{cv}$. Gladis fruit (Table 1, Additional file 4: Table S3). Taken across all three treatments, the As content was at least twice as high in cv. Aragon than in cv. Gladis fruits. With respect to the fruits' $\mathrm{Si}$ content, concentrations were consistently higher in cv. Aragon than in cv. Gladis fruits harvested from plants exposed to either the As or the nt treatments, but this cultivar difference disappeared in fruits set by plants exposed to As $+\mathrm{Si}$ (Table 1). Si concentrations within the fruits significantly decreased during time for the NT and the As treated plants, but not for the As + Si. In particular, at t14d, Si concentrations were consistently higher in Aragon for NT and As treatments, but not significantly different among the two cvs for the As + Si treatment (Table 1 and Additional file 4: Table S3). Apparently, at t14d, As treatment alone competed with $\mathrm{Si}$ for allocation within the fruits, but the concomitant administration of $\mathrm{Si}$ with As resulted in an increase of $\mathrm{Si}$, in agreement with its role as a protecting agent against stressors, in this case As [43].

\section{The tomato fruit proteome}

The 2DE profiling generated overall about 900 visible features for each cultivar. To allow consistent MALDITOF analysis the effective number of the reproducible spots in the fruit proteome of cv. Aragon and in that of cv. Gladis were 396 and 349 respectively (Additional file 5: Figure S2A, B). Among the former set, 22 varied in intensity in response to the treatments: 16 of these were identified from the contrast nt vs As, 9 from the contrast nt vs $\mathrm{As}+\mathrm{Si}$ and 14 from the contrast As vs $\mathrm{As}+\mathrm{Si}$; among the cv. Gladis set, the number of variable features was 30, distributed among the three contrasts as, respectively 18, 9 and 15 (Fig. 1). Only 4 of the variable features were common to both cultivars, namely an F-box/WD-40 repeat-containing protein (At5G21040like), a growth-regulating factor 9-like protein, alcohol dehydrogenase 2 and an ADP/ATP translocator. The identity of the two sets of variable features is given in Table 2, and the associated heat maps illustrating their relative abundance are shown in Additional file 6: Figure S3. Their MapMan ontology BIN assignations (covering 35 BINs) are listed in Additional file 4: Table S3.

As shown in Fig. 2a and b, the set of reprogrammed fruit proteins in both cultivars were associated with signaling, protein synthesis, protein degradation, RNA regulation of transcription, hormone metabolism, lipid metabolism, major carbohydrate metabolism, fermentation, photosynthesis, cell, abiotic stress and biotic stress. The BIN RNA binding, RNA processing and transport were found only in CV. Aragon's fruit proteins; protein folding, protein modification, RNA transcription, cofactor and vitamin metabolism, minor carbohydrate metabolism, amino acid metabolism, secondary metabolism, transport, glycolysis, cell wall, development, redoxascorbate and glutathione, miscellaneous cytochrome P450 and metal handling were found only in cv. Gladis' fruit proteins. Their abundance and function are shown in Fig. 3a and b. Further details are provided in Additional file 4: Table S5A and B.

\section{Discussion}

Fruit proteins reprogrammed by $\mathrm{As}$ and/or $\mathrm{As}+\mathrm{Si}$ treatments in cv. Aragon

The stress-induced reprogramming of proteins involved in transcription, signaling and hormone metabolism,

\section{Aragon}
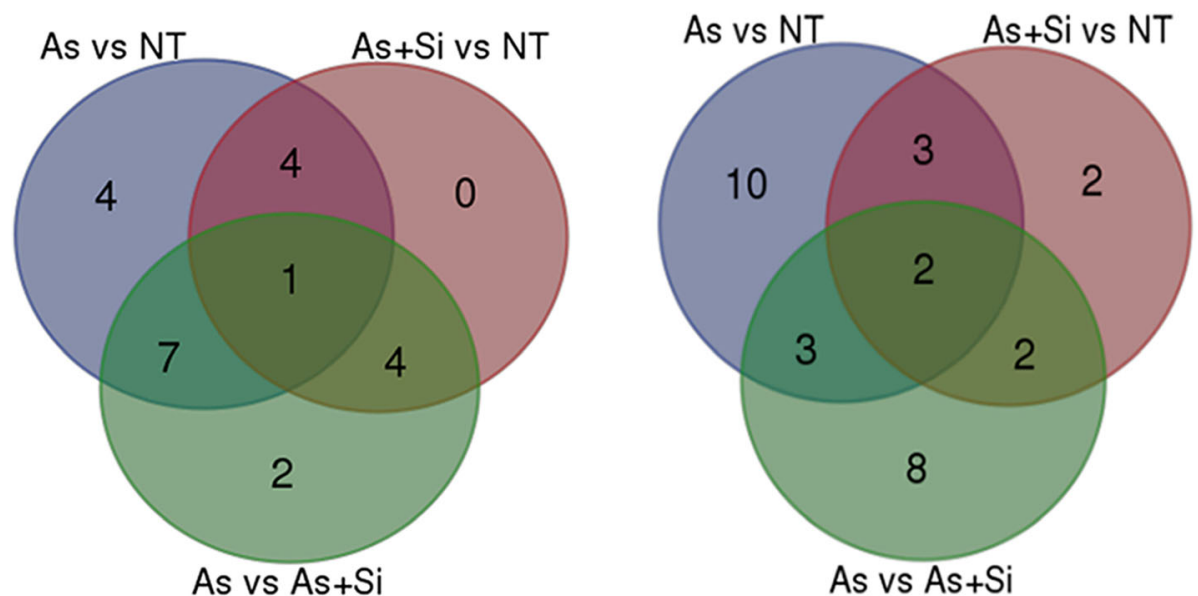

Fig. 1 Full set of reprogrammed proteins. The sets of fruit proteins differing significantly $(p<0.05)$ in their abundance in the treatment contrasts $n t$ vs As, nt vs As + Si and As vs As + Si 
Marmiroli et al. BMC Plant Biology (2017) 17:210

Page 6 of 15

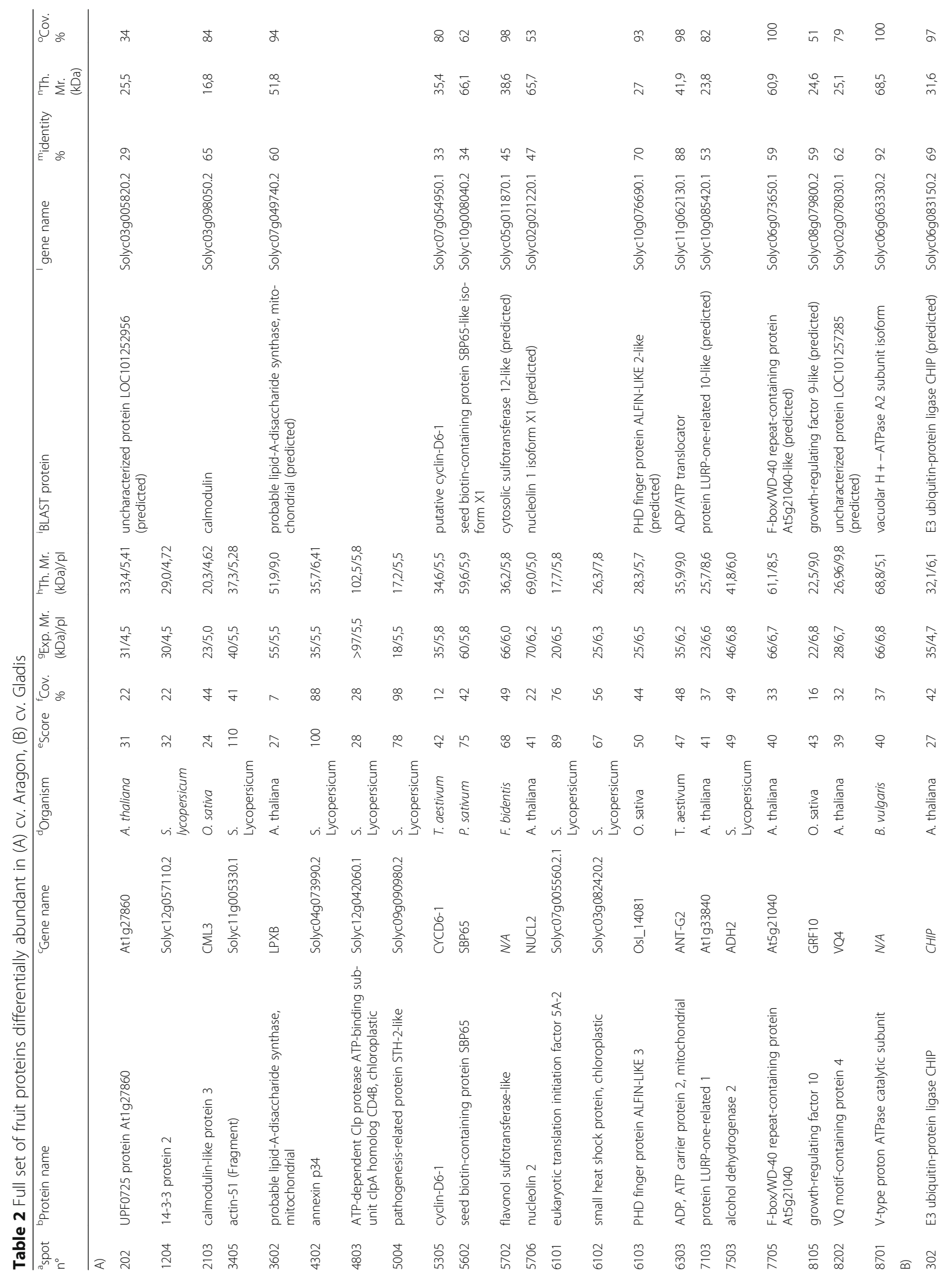


Marmiroli et al. BMC Plant Biology (2017) 17:210

Page 7 of 15

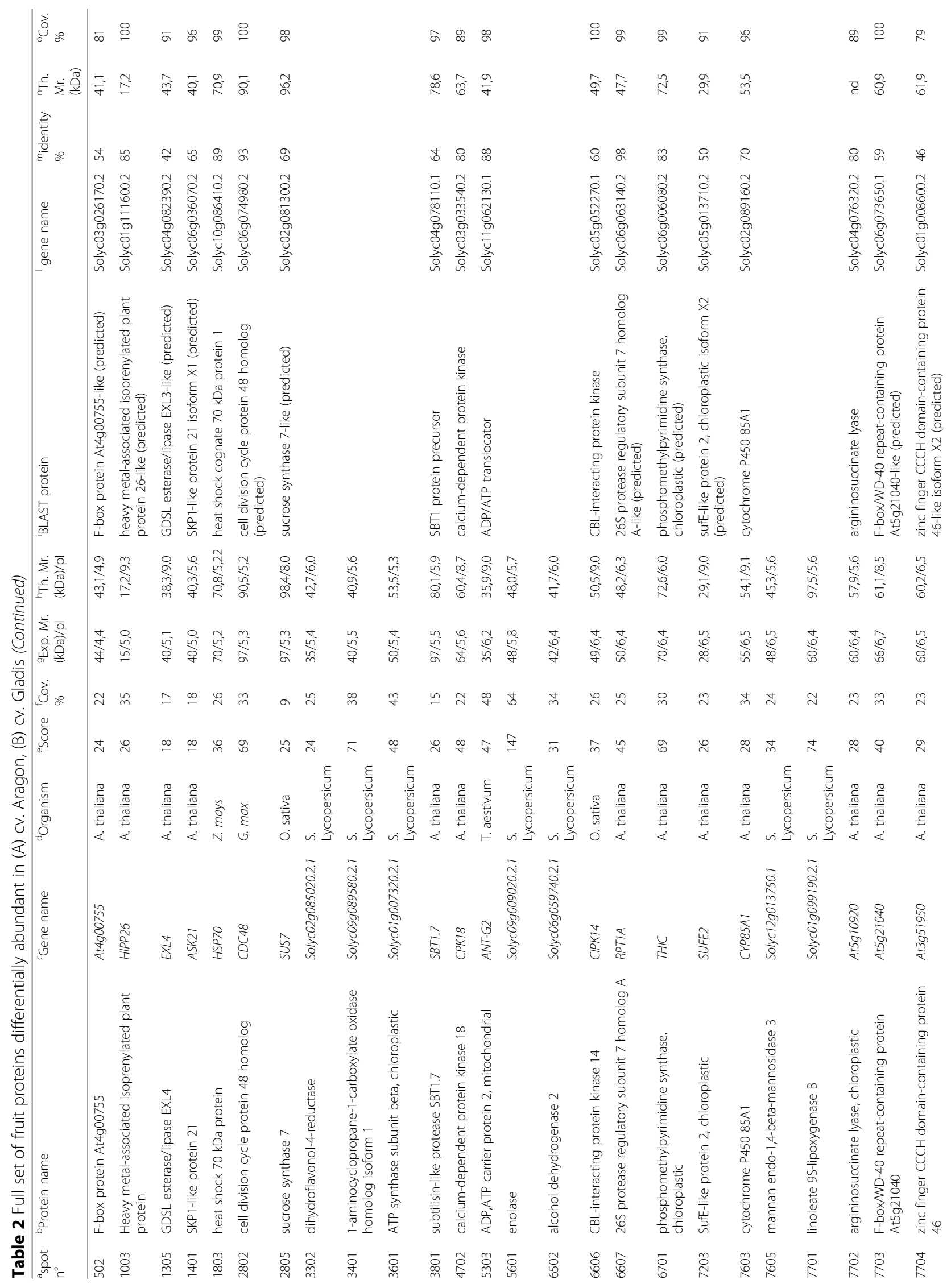




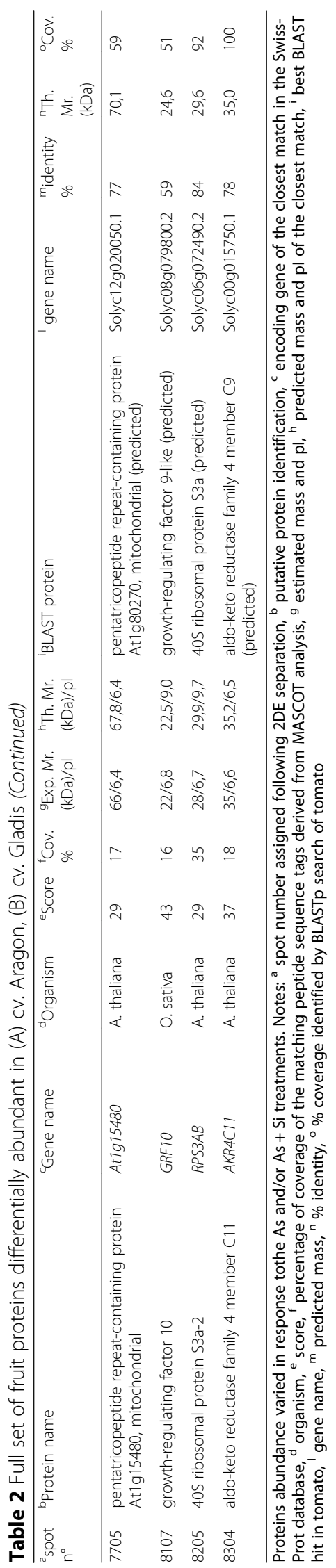


transport and cell may have arisen as a result of the impact of the treatments on the ripening process, which involves extensive changes to the transcriptome, proteome and metabolome [2, 3, 9] (Figs. 2 and 3a, Additional file 4: Table S5A). The As treatment affected transcription-, signaling- and hormone-related proteins, all of which are involved in the direct and retrograde communication between the nucleus and the organelles; their modulation could well disturb the normal development of the fruit $[10,53]$. Proteins related to transport and cell metabolism, also essential for ripening, probably served as a means for the tissue to sequester As into non-essential cellular structures and to increase the concentration of antioxidants needed to maintain an appropriate cellular redox state [54]. Supplementation with Si had a marked influence over the abundance of proteins associated with transcription, signaling and hormone metabolism, as also noted in the interaction of tomato with its pathogen $\mathrm{Ral}$ stonia solanacearum [55]. The protective action of $\mathrm{Si}$ against pathogen attack has been characterized by an accumulation of various defense-associated transcription factors (here, members of the WRKY family), signaling proteins (calmodulin and 14-3-3 protein 2) and the modulation of endogenous hormone synthesis [56]. An altered abundance of proteins determining cell shape and the cytoskeleton (such as actin and annexin) has been shown to be associated with ripening [8-11]. Some of these were induced by the As treatment, presumably because of the oxidative stress thereby imposed, which in turn was likely to have encouraged the peroxidation of membrane lipids, leading to intra-cellular electron leakage [57]. Si has a suppressive effect on cellular free radical content, thereby alleviating lipid peroxidation [58]. A reduced need for cell shape adjustment following the Si-enabled stabilization of cell membranes and reduction in free radical content could explain the fall in abundance of proteins related to cell shape and structure development. A possible detrimental effect of As on the ripening process may have been exerted by the lowered abundance of Clp protease $\mathrm{CD} 4 \mathrm{~B}$ and the small heatshock protein HSP21, both of which are essential for, respectively, chromoplast development and fruit color change [11]; the abundance of both these proteins was enhanced by the provision of Si.

\section{Fruit proteins reprogrammed by $\mathrm{As}$ and/or $\mathrm{As}+\mathrm{Si}$ treatments in cv. Gladis}

The abundance of several proteins belonging to the ubiquitin-proteasome system (UPS), an essential component of the regulatory network controlling the abundance of a number of enzymes, along with certain structural and regulatory proteins [59], was affected by the treatments (Figs. 2 and 3b, Additional file 4: Table $\mathrm{S} 5 \mathrm{~B})$. The added proteomic flexibility provided by the
UPS provides a means of adapting to an episode of abiotic stress [60]. The abundance of the three hormone synthesis-associated proteins 1-aminocyclopropane-1carboxylate oxidase, cytochrome P450 85A1 and linoleate 9S-lipoxygenase $\mathrm{B}$ was lower in fruits harvested from plants subjected to both the As and the As + Si treatments than in plant from the nt treatment. The $26 \mathrm{~S}$ proteasome complex is of particular interest in the context of the plant response to As, because in A. thaliana, the F subunit of the 20S core particle has been shown to be responsible for the increased As tolerance shown by the ars5 mutant [61]. Here, the reprogramming concerned a subunit of the $19 \mathrm{~S}$ rather than the $20 \mathrm{~S}$ particle. Wang et al. [53] have shown that 12 of the 13 proteins represented in the $26 \mathrm{~S}$ proteasome complex are highly abundant in ripe tomato fruits. Supplementation with Si was unable to restore the level of these proteins to the $\mathrm{nt}$ level, perhaps because the fruits' As concentration was higher in the As + Si than in the As treatment, resulting in a higher As/Si ratio (Table 1). Proteins related to protein synthesis, folding and modification were affected to a different degree by the two treatments: the pattern was inconsistent, probably because the abundance of these proteins is so strongly influenced by the ripening process $[53,62]$. In particular, AKR (aldo/keto reductase), an enzyme known to contribute to abiotic stress tolerance [63], typically increases during the course of early fruit development, and declines during the red ripening stage [64]. AKR was under-abundant in the As treatment and undetectable in the $\mathrm{As}+\mathrm{Si}$ treatment, indicating a possible acceleration in the ripening process induced by both treatments. AKR contributes to the detoxification of malondialdehyde [65], so its suppression in the As + $\mathrm{Si}$ treatment is consistent with the protective action of $\mathrm{Si}$ against lipid peroxidation. Several proteins involved in carbon metabolism and ATP production were underabundant in the As treatment, in accordance with the documented detrimental effect of this element on respiration and photosynthesis $[17,23]$. The concentration of the glycolysis enzyme enolase was substantially raised by Si supplementation, in keeping with the proposed contribution of $\mathrm{Si}$ to the alleviation of As stress [43]. The abundance of a number of secondary metabolismrelated proteins was noted in the fruits of the As treated plants, an effect which was reversed in the As + Si treatment. A sharp increase in secondary metabolite content is a feature of fruit maturation, as the plant needs to deal with a rise in oxidant activity $[9,11]$; in this regard both treatments appeared to perturb the amount of enzymes required during the fruit ripening process. Proteins related to cell wall structure are of relevance because both As and Si can affect cell wall organization [66, 67]. Si contributes to the alleviation of stress, not just via its enhancement of cell wall deposition [68], but also by its 


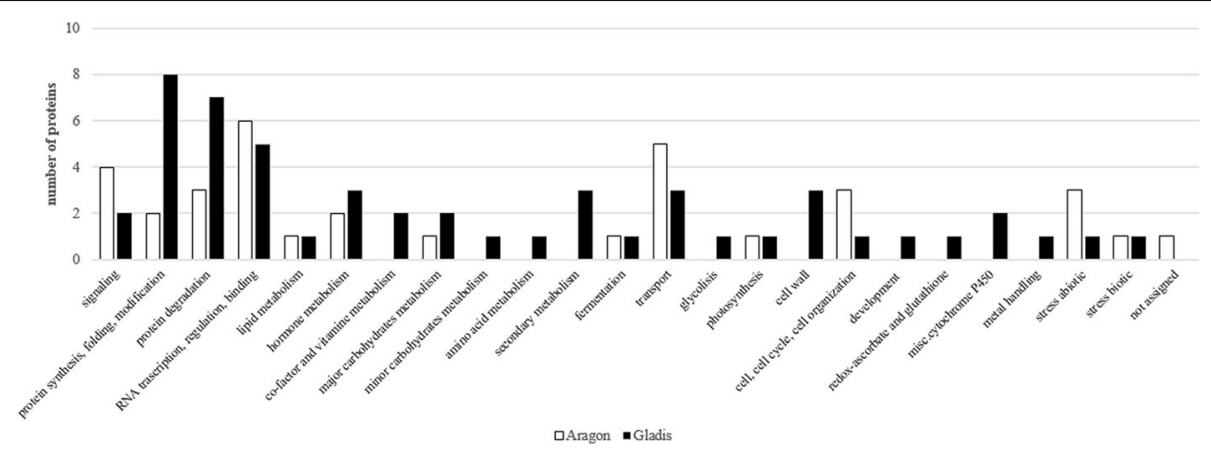

Fig. 2 Responsive proteins according to MapMan ontology. The distribution of responsive proteins in the fruit of cv. Aragon and cv. Gladis, according to MapMan ontology classification

stimulation of cell wall component synthesis [69]. Structural changes to the cell wall during ripening involve pectins, hemicelluloses and cellulose [70]. In the tomato fruit, the expression level of a gene encoding endo- $\beta$ mannanase has been shown to increase markedly at the

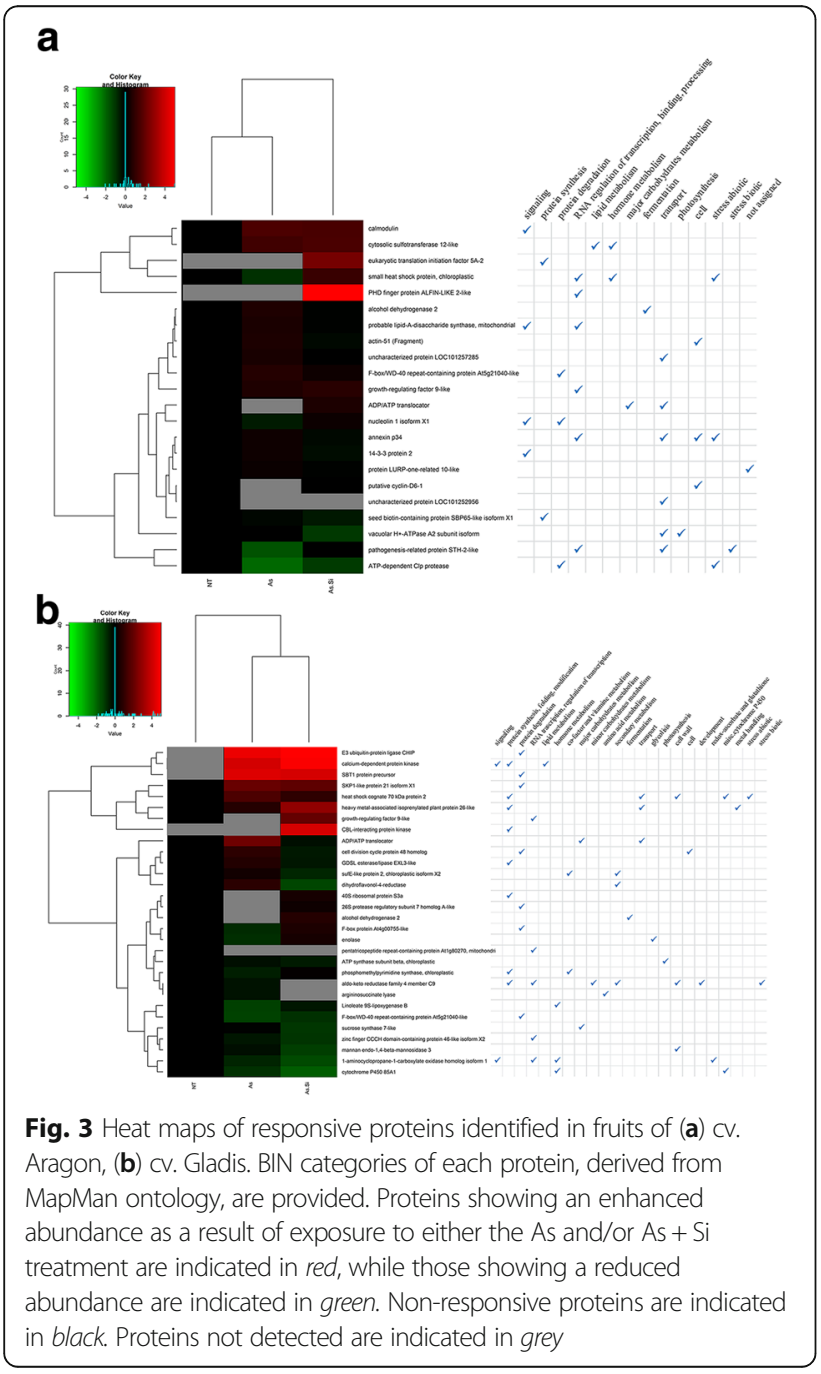

breaker stage and to remain high throughout the red and over-ripe stages [71]. This enzyme has also been found to accumulate in response to parasite attack, suggesting its active involvement in the stress response [72]. It is thus possible that $\mathrm{Si}$ influences the concentrations of this and similar proteins within its broader priming effect mentioned above. Here, the under-abundance of mannosidases may have induced an increase in the cellulose content, tightening cellulose networks and strengthening cell wall stability.

\section{MapMan pathways identified in tomato fruit under As and As + Si treatment}

Metabolic pathways associated with the cellular status of the fruits set by cvs Aragon and Gladis were derived using MapMan software, based on the Slyc_ITAG2.3 database (solgenomics.net/gb2/gbrowse/ITAG2.3_genomic/). The highest scoring processes (Fig. 4, Additional file 7: Figure S4, Additional file 8: Figure S5) were "cell function overview" and "biotic stress pathway" for both cultivars, with the addition of "proteosome" for $\mathrm{cv}$. Gladis.

The "cell function overview" assigned 19 of the 21 mapped proteins in the cv. Aragon fruits to nine processes, namely: "cell division and cell cycle", "regulation of transcription", "protein synthesis and amino acid activation", "protein degradation", "enzyme families", "cell organization", "RNA processing", "regulation", and "transport" (Fig. 4a, b). Of the 30 proteins in cv. Gladis 21 were assigned within the "cell function overview" to the first five categories mentioned for cv. Aragon. The reminder proteins were assigned to: "stress biotic and abiotic", "hormones", "protein modification", and "metal handling" (Fig. 4c, d). The 14 proteins assigned to the "biotic stress pathway" were associated with "hormone signaling", "cell wall", "proteolysis", "heat shock proteins" and "secondary metabolites", while of the eight assigned to "proteolysis", six were associated with the "proteasome" (Additional file 8: Figure S5). A subset of the 

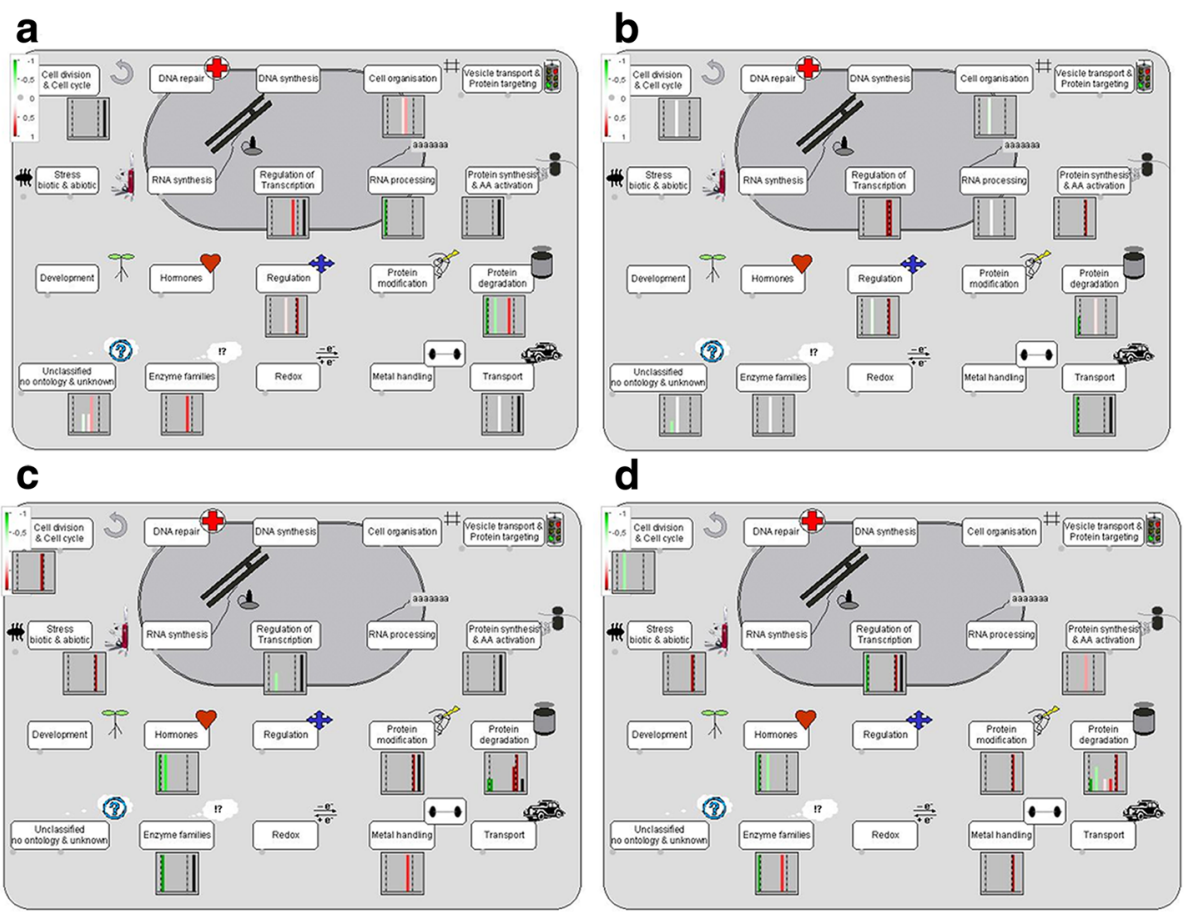

Fig. 4 MapMan Cell function overview of the differentially abundant tomato fruit proteins. Cell function overview of the differentially abundant tomato fruit proteins in $(\mathbf{a}, \mathbf{b}) \mathbf{c v}$. Aragon, $(\mathbf{c}, \mathbf{d}) \mathrm{cv}$. Gladis in response to $(\mathbf{a}, \mathbf{c})$ the As and $(\mathbf{b}$, d) the As + Si treatmentsProteins showing an enhanced or a reduced abundance as a result of the treatment are marked in, respectively, red and green. Proteins not detected are indicated in black

proteins identified from fruits harvested from plants of the two cultivars subjected to either the As or the As + Si treatment belonged to the same cell function processes, namely "cell division and cell cycle", "regulation of transcription", "protein synthesis and amino acid activation", "protein degradation" and "enzyme families". Overall, those reprogrammed in cv. Aragon were largely associated with the regulation of transcription, cell organization, transport and RNA processing, while those in cv. Gladis were involved in protein synthesis, transformation, ubiquitination and proteolysis and hormones. The MapMan pathway analysis highlighted the distinct strategies adopted by the two cultivars to cope with Asinduced stress, as well as the different ways in which the provision of Si mitigated these effects. Proteins implicated in the biotic stress response were reprogrammed in the fruits of both cultivars, but there were differences with respect to the major classes of proteins involved (Additional file 7: Figure S4). For example, transcription regulation, cell organization-, signaling- and transportassociated proteins were prominent in cv. Aragon fruits, whereas in cv. Gladis fruits, the main categories were protein modification, protein degradation and hormones (Fig. 4, Additional file 8: Figure S5). The fruits set by cv. Gladis plants subjected to the As or the As + Si treatments featured a higher number of reprogrammed proteins related specifically to the biotic stress response.

\section{Reprogrammed proteins associated with the stress response}

The two sets of reprogrammed proteins were grouped into sub-sets related to the As stress response, the abiotic stress response, fruit development and ripening (Additional file 4: Table S4); the respective heat maps are given in Fig. 5. In cv. Aragon fruits, four proteins implicated in the As stress response were consistently reprogrammed in response to both the As and the As + Si treatments. Several proteins involved in the abiotic stress response were also affected by ripening, although there are no precedents in the literature for this connection. Four proteins classed as highly abundant during fruit development and ripening $[9,53,62]$ were reduced in abundance or suppressed altogether in the fruits harvested from plants subjected to the As treatment, and the addition of Si only partially reversed these effects. The behavior of five $\mathrm{cv}$. Gladis proteins previously implicated in the As stress response [73, 74] was confirmed here, but this was not the case for either ADK or enolase, which have been claimed to be inducible by As exposure by, respectively, Paulose et al. [75] and Tripathi et al. [34], whereas in the present experiment, both were reduced in abundance by the treatment. Five further proteins, which responded to fruit development and ripening according to Faurobert et al. (2007) [9] and Suzuki et al. [8], were here either partially or completely suppressed by the As treatment; however, Si supplementation counteracted the effect for three 


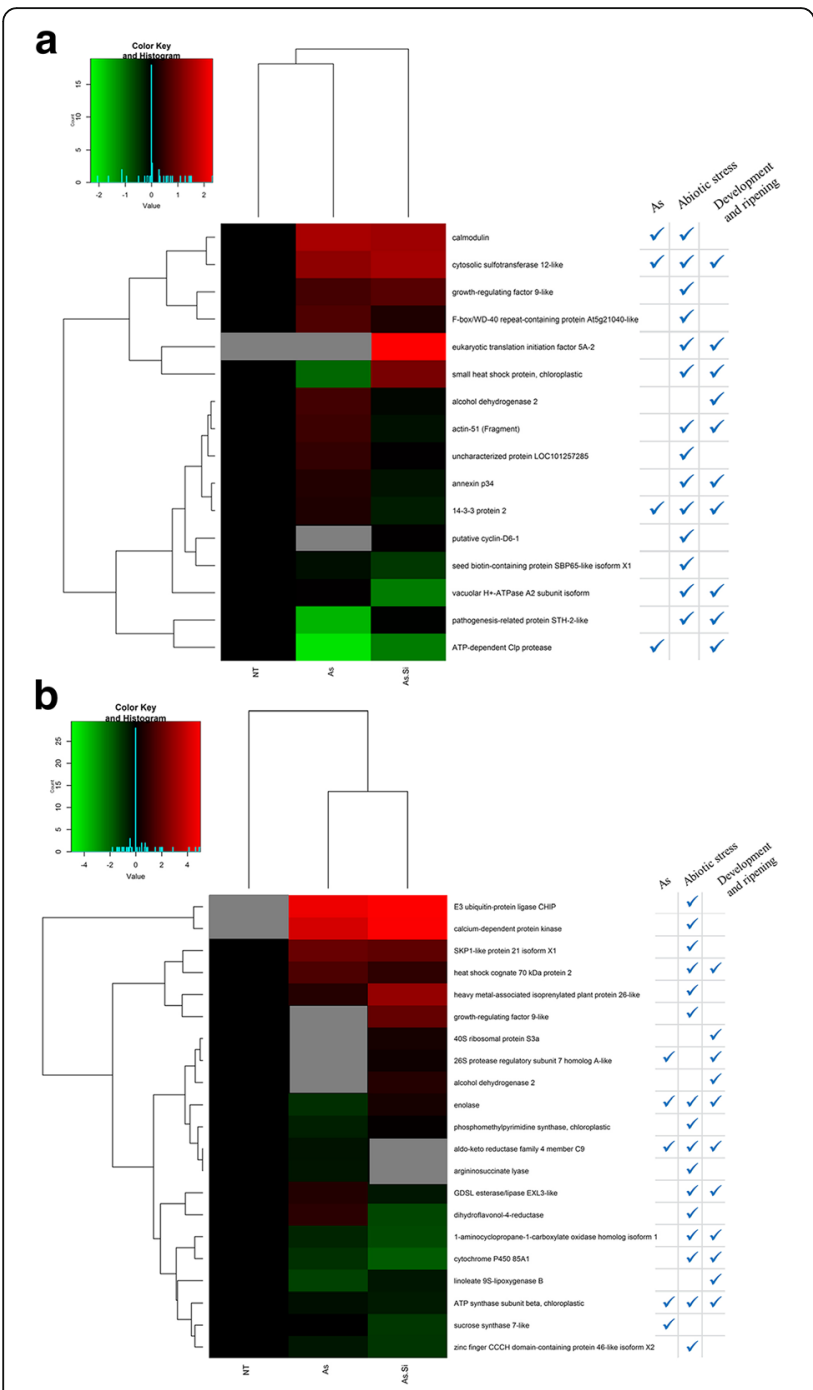

Fig. 5 Alternative classification for the differentially abundant fruit proteins in (a) Cv. Aragon, (b). Heat map of the set of differentially abundant fruit proteins identified in (a) cv. Aragon, (b) cv. Gladis, with an indication of their documented involvement in the As stress response, the abiotic stress response, fruit development or ripening. Proteins showing an enhanced abundance as a result of exposure to either the As and/or As + Si treatment are indicated in red, while those showing a reduced abundance are indicated in green. Nonresponsive proteins are indicated in black. Proteins not detected are indicated in grey

of the five proteins. Finally, several proteins associated with the abiotic stress response, specifically chloroplastic ATPdependent Clp protease ATP-binding subunit clpA homo$\log \mathrm{CD} 4 \mathrm{~B}$ and linoleate 9S-lipoxygenase $\mathrm{B}[76,77]$ were modulated by both the As and $\mathrm{As}+\mathrm{Si}$ treatments, while the abundance of both cytosolic sulfotransferase (involved in the As response, see Komatsu et al., [78]) and sucrose synthase 7-like (general abiotic stress response, see Hirschmann et al., [79]) was here correlated with fruit ripening (Fig. 5, Additional file 4: Table S5).

\section{Conclusions}

The deleterious effect of As and the alleviating role of $\mathrm{Si}$ are an interesting example of the complexity in plantenvironment interaction. All of these depends on uptake from the media of As and $\mathrm{Si}$, on their transport to the different parts of the plant and on the activation of response mechanisms which are tissue/organ specific. Whereas the effect of As treatment, and its modulation by the supply of $\mathrm{Si}$, on the root, leaf and seed of several plant species has been examined in some detail $[23,33,80]$, the present report constitutes a first attempt to investigate the consequences of their presence for the fruit proteome which is highly dynamic because of the many and rapid changes which take place during the ripening process $[9,81]$. Despite their apparent genetic similarity, the two tomato cultivars compared here have been shown previously to differ in their response to As and As + Si treatment, for example to the extent to which they accumulate these elements in their fruit [34]. To date, in the tomato genome no orthologous sequence of AtNIP5;1, OsLsi1, OsLsi2 or other As/Si specific transporters has been cloned [82]. Still, the existing competition between $\mathrm{As}$ and $\mathrm{Si}$ in allocation within the fruit might argue favorably for the existence of common transport mechanisms. We found that only five proteins were related to signal transduction in each cultivar for all treatments (Fig. 3); in general the main class of proteins readjusted by $\mathrm{As}$ and $\mathrm{As}+\mathrm{Si}$ were related to RNA regulation and transcription, transport, and protein degradation, but the two cultivars showed notable differences. In $\mathrm{cv}$. Aragon reprogramming of transcription factors and ATP/ADP transporters indicated that $\mathrm{As}$ and $\mathrm{As}+\mathrm{Si}$ could act on DNA and ribosomal activity. In cv. Gladis, $\mathrm{As}$ and $\mathrm{As}+\mathrm{Si}$ modulated mostly proteins involved in proteins synthesis, folding and degradation, specifically the proteasome complex, bearing out possible alteration in the enzymatic pool acting in the ripening process.

This protein reprogramming in the fruit proteome is accompanied with the biosynthesis of antioxidant and stress protecting metabolites as carotenoids, phenolics, glutathione and ascorbic acid (Marmiroli et al. unpublished data), which contribute to maintain the fruit homeostasis.

\section{Additional files}

Additional file 1: Figure S1. Scatter plot of detected spots on 2D gel: a) Aragon, and b) Gladis. (PDF $536 \mathrm{~kb}$ )

Additional file 2: Table S1. MALDI-TOF/TOF data associated with differentially abundant fruit proteins identified in (A) CV. Aragon and (B) cv. Gladis. See attached excels file. (XLSX 58 kb)

Additional file 3: Table S2. Protein abundance data. See attached excels file. (XLSX $28 \mathrm{~kb}$ )

Additional file 4: Table S3. Three-ways ANOVA for As and Si concentrations in fruits of tomato cultivars Aragon and Gladis. Table S4. MapMan BIN assignation of the differentially abundant fruit proteins in 
(A) cv. Aragon, (B) cv. Gladis. Table S5. Description of the differentially abundant fruit proteins in (A) CV. Aragon, (B) Cv. Gladis. (DOCX $90 \mathrm{~kb}$ )

Additional file 5: Figure S2. 2D gel electrophoresis images of fruit proteins from A) Aragon, and B) Gladis. (PDF 973 kb)

Additional file 6: Figure S3. Heat map of the differentially abundant proteins present in A) Aragon, B) Gladis. (PDF 737 kb)

Additional file 7: Figure S4. Representation of the differentially Differentially abundant fruit proteins involved in the "Biotic Stress" response MapMan pathway. (PDF 578 kb)

Additional file 8: Figure S5. Representation of the dDifferentially abundant fruit proteins in Gladis involved in the "Ubiquitin Dependent Degradation" MapMan. (PDF 444 kb)

\section{Abbreviations}

2DE: Two dimensional gel electrophoresis; 4-HCCA: a-cyano-4hydroxycinnamic acid; Cl: Confidence interval; DTT: Dithiothreitol: EC: Electrical conductivity; EDTA: Ethylenediamine tetra acetic acid; IEF: Isoelectofocusing; ROS: reactive oxygen species; SDS PAGE: Sodium dodecyl sulphate polyacrylamide gel electrophoresis; SDS: Sodium dodecyl sulfate; Treatments: "nt" = non-treated control, "As" = treatment with As only, "As + $\mathrm{Si} "=$ treatment with As in combination with $\mathrm{Si}$

\section{Acknowledgments}

The authors acknowledge the assistance of Gianluca Paredi (Department of Pharmacy, University of Parma) for MS analysis, of CIM (Parma, Italy) for access to MALDI-TOF-MS facilities, and of Giacomo Lencioni and Nicola Cavirani (Department of Chemistry, Life Sciences and Environmental Sustainability, University of Parma, Parma, Italy) for helping with the growing and sampling of plants. The authors wish to thank Robert Koebner for editing the manuscript.

\section{Funding}

Not applicable.

\section{Availability of data and materials}

A part of the data were provided in Additional file 2: Table S1 and Additional file 3: Table S2

The raw datasets used and/or analyzed during the current study are available from the corresponding author on reasonable request.

\section{Authors' contributions}

MM designed and performed the experiment, interpreted the results, and wrote the manuscript. FM performed the experiments, assisted in the data analysis and manuscript draft. DI assisted in the experiments and data analysis. NM provided guidance during the study, the manuscript writing and contributed in general to this work. All authors have read and approved the final manuscript.

\section{Ethics approval and consent to participate}

The seeds of cvs. Aragon and Gladis were provided by ESASEM s.p.a., Casaleone, Verona, Italy. The cultivars are all subject to plant breeders' rights, and pedigree information is not publicly available.

\section{Consent for publication}

Not applicable.

\section{Competing interests}

The authors declare that they have no competing interests.

\section{Publisher's Note}

Springer Nature remains neutral with regard to jurisdictional claims in published maps and institutional affiliations.

\section{Author details}

${ }^{1}$ Department of Chemistry, Life Sciences and Environmental Sustainability, University of Parma, Parco Area delle Scienze 33/A, 43124 Parma, Italy. 2Department of Chemistry, Life Sciences and Environmental Sustainability, University of Parma, Parco Area delle Scienze 11/A, 43124 Parma, Italy.
Received: 5 June 2017 Accepted: 10 November 2017

Published online: 21 November 2017

\section{References}

1. Tanksley SD. The genetic, developmental, and molecular bases of fruit size in tomato and shape variation. Plant Cell. 2009;16:181-90.

2. Klee HJ, Giovannoni JJ. Genetics and control of tomato fruit ripening and quality attributes. Annu Rev Genet. 2011;45:41-59.

3. Pesaresi P, Mizzotti C, Colombo M, Masiero S. Genetic regulation and structural changes during tomato fruit development and ripening. Front Plant Sci. 2014:5:124

4. Gillaspy G, Ben-David H, Gruissem W. Fruits: a developmental perspective. Plant Cell. 1993:5:1439-51.

5. Bergervoet JHW, Berhoeven HA, LWW G, Bino RJ. High amounts of nuclear DNA in tomato (Lycopersicon esculentum mill.) pericarp. Plant Sci. 1996:116:141-5.

6. Ho LC, Hewitt JD. Fruit development In The Tomato Crop. Springer Netherlands, editor. 1986.

7. Gapper NE, Giovannoni JJ, Watkins CB. Understanding development and ripening of fruit crops in an "omics" era. Hortic Res. 2014;1:14034.

8. Suzuki M, Takahashi S, Kondo T, Dohra H, Ito $Y$, Kiriiwa $Y$, et al. Plastid proteomic analysis in tomato fruit development. PLoS One. 2015;10:1-25.

9. Faurobert M, Mihr C, Bertin N, Pawlowski T, Negroni L, Sommerer N, et al. Major proteome variations associated with cherry tomato Pericarp development and ripening. Plant Physiol. 2007;143:1327-46.

10. Xu J, Pascual L, Aurand R, Bouchet JP, Valot B, Zivy M, et al. An extensive proteome map of tomato (Solanum lycopersicum) fruit pericarp. Proteomics. 2013;13:3059-63.

11. Barsan C, Zouine M, Maza E, Bian W, Egea I, Rossignol M, et al. Proteomic analysis of chloroplast-to-chromoplast transition in tomato reveals metabolic shifts coupled with disrupted Thylakoid biogenesis machinery and elevated energy-production components. Plant Physiol. 2012;160:70825.

12. Mandal BK, Suzuki KT. Arsenic round the world: A review. Talanta. 2002;58: 201-352.

13. Bhattacharya P, Welch AH, Stollenwerk KG, McLaughlin MJ, Bundschuh J, Panaullah G. Arsenic in the environment: biology and chemistry. Sci Total Environ. 2007:379:109-20.

14. Ng JC, Wang J, Shraim A. A global health problem caused by arsenic from natural sources. Chemosphere. 2003:52:1353-9.

15. Singh R, Singh S, Parihar P, Singh VP, Prasad SM. Arsenic contamination, consequences and remediation techniques: a review. Ecotoxicol Environ Saf. Elsevier. 2015;112:247-70.

16. Punshon T, Jackson BP, Meharg AA, Warczack T, Scheckel K, Guerinot ML. Understanding arsenic dynamics in agronomic systems to predict and prevent uptake by crop plants. Sci Total Environ Elsevier BV. 2016;582:209-20.

17. Zhao FJ, Ma JF, Meharg AA, McGrath SP. Arsenic uptake and metabolism in plants. New Phytol. 2009;181:777-94.

18. Finnegan PM, Chen W. Arsenic toxicity: the effects on plant metabolism Front Physiol. 2012;3:1-18.

19. Sharma I. Arsenic induced oxidative stress in plants. Biologia (Bratisl). 2012 67:447-53.

20. Al-Aghabary K, Zhu Z, Shi Q. Influence of silicon supply on chlorophyll content, chlorophyll fluorescence, and antioxidative enzyme activities in tomato plants under salt stress. J Plant Nutr. 2004;27:2101-15.

21. Guo W, Hou YL, Wang SG, Zhu YG. Effect of silicate on the growth and arsenate uptake by rice (Oryza sativa L.) seedlings in solution culture. Plant Soil. 2005;272:173-81.

22. Liang Y, Sun W, Zhu YG, Christie P. Mechanisms of silicon-mediated alleviation of abiotic stresses in higher plants: a review. Environ Pollut. 2007; 147:422-8.

23. Sanglard LMVP, Martins SCV, Detmann KC, Silva PEM, Lavinsky AO, Silva MM, et al. Silicon nutrition alleviates the negative impacts of arsenic on the photosynthetic apparatus of rice leaves: an analysis of the key limitations of photosynthesis. Physiol Plant. 2014;152:355-66

24. Adrees M, Ali S, Rizwan M, Zia-ur-Rehman M, Ibrahim M, Abbas F, et al. Mechanisms of silicon-mediated alleviation of heavy metal toxicity in plants: a review. Ecotoxicol Environ Saf. 2015;119:186-97.

25. Pandey C, Khan E, Panthri M, Tripathi RD, Gupta M. Impact of silicon on Indian mustard (Brassica juncea L.) root traits by regulating growth parameters, cellular antioxidants and stress modulators under arsenic stress. Plant Physiol. Biochemist. 2016;104:216-25. 
26. Requejo R, Tena M. Proteome analysis of maize roots reveals that oxidative stress is a main contributing factor to plant arsenic toxicity. Phytochemistry. 2005;66:1519-28

27. Wu J, Guo J, Hu Y, Gong H. Distinct physiological responses of tomato and cucumber plants in silicon-mediated alleviation of cadmium stress. Front Plant Sci. 2015:6:1-14.

28. Ma JF, Yamaji N, Mitani N, Xu X, Su Y, McGrath SP, et al. Transporters of arsenite in rice and their role in arsenic accumulation in rice grain. Proc Natl Acad Sci U S A. 2008;105:9931-5.

29. Hu H, Zhang J, Wang H, Li R, Pan F, Wu J, et al. Effect of silicate supplementation on the alleviation of arsenite toxicity in 93-11 (Oryza sativa L. indica). Environ Sci Pollut Res. 2013;20:8579-89.

30. Romero-Aranda MR, Jurado O, Cuartero J. Silicon alleviates the deleterious salt effect on tomato plant growth by improving plant water status. J Plant Physiol. 2006;163:847-55.

31. Marmiroli M, Pigoni V, Savo-Sardaro ML, Marmiroli N. The effect of silicon on the uptake and translocation of arsenic in tomato (Solanum lycopersicum L.). Environ Exp Bot. 2014;99:9-17.

32. Clemens S, Ma JF. Toxic heavy metal and metalloid accumulation in crop plants and foods. Annu Rev Plant Biol. 2016;67:489-512.

33. Goupil P, Souguir D, Ferjani E, Faure O, Hitmi A, Ledoigt G. Expression of stress-related genes in tomato plants exposed to arsenic and chromium in nutrient solution. J Plant Physiol. 2009;166:1446-52.

34. Tripathi RD, Tripathi P, Dwivedi S, Dubey S, Chatterjee S, Chakrabarty D, et al. Arsenomics: Omics of arsenic metabolism in plants. Front Physiol. 2012;3:1-14.

35. Kumar V, Irfan M, Ghosh S, Chakraborty N, Chakraborty S, Datta A. Fruit ripening mutants reveal cell metabolism and redox state during ripening. Protoplasma. 2016;253:581-94.

36. McCullough ML, Giovannucci EL. Diet and cancer prevention. Oncogene. 2004:23:6349-64

37. Tohge T, Fernie AR. Metabolomics-inspired insight into developmental, environmental and genetic aspects of tomato fruit chemical composition and quality. Plant Cell Physiol. 2014;56:1681-96.

38. Rohrmann J, Tohge T, Alba R, Osorio S, Caldana C, McQuinn R, et al. Combined transcription factor profiling, microarray analysis and metabolite profiling reveals the transcriptional control of metabolic shifts occurring during tomato fruit development. Plant J. 2011;68:999-1013.

39. Ghosh S, Narula K, Sinha A, Ghosh R, Jawa P, Chakraborty N, et al. Proteometabolomic analysis of transgenic tomato overexpressing oxalate decarboxylase uncovers novel proteins potentially involved in defense mechanism against Sclerotinia. J Proteome. 2016;143:242-53.

40. D'Esposito D, Ferriello F, Molin AD, Diretto G, Sacco A, Minio A, et al. Unraveling the complexity of transcriptomic, metabolomic and quality environmental response of tomato fruit. BMC Plant Biol. 2017:1-18.

41. Panthee DR, Cao C, Debenport SJ, Rodriguez GR, Labate JA, Robertson LD, et al. Magnitude of genotype $\times$ environment interactions affecting tomato fruit quality. Hortscience. 2012;47:721-6.

42. Rocco M, D'Ambrosio C, Arena S, Faurobert M, Scaloni A, Marra M. Proteomic analysis of tomato fruits from two ecotypes during ripening. Proteomics. 2006;6:3781-91.

43. Sanglard LMVP, Detmann KC, Martins SCV, Teixeira RA, Pereira LF, Sanglard $M L$, et al. The role of silicon in metabolic acclimation of rice plants challenged with arsenic. Environ Exp Bot Elsevier B.V. 2016;123:22-36.

44. van der Vorm PDJ. Dry ashing of plant material and dissolution of the ash in $\mathrm{HF}$ for the colorimetric determination of silicon. Commun. Soil Sci Plant Anal. 1987;18:1181-9.

45. Ramagli LS, Rodriguez LV. Quantitation of microgram amounts of protein in SDS-mercaptoethanol-tris electrophoresis sample buffer. Electrophoresis. 1985:559-63.

46. Shevchenko A, Tomas H, Havlis J, Olsen JV, Mann M. In-gel digestion for mass spectrometric characterization of proteins and proteomes. Nat PRO. 2006;1:2856-60

47. Ramšak Ž, Baebler Š, Rotter A, Korbar M, Mozetič I, Usadel B, et al. GoMapMan: integration, consolidation and visualization of plant gene annotations within the MapMan ontology. Nucleic Acids Res. 2014;42:1167-75

48. Burló F, Guijarro I, Carbonell-Barrachina AA, Valero D, Martínez-Sánchez F. Arsenic species: effects on and accumulation by tomato plants. J Agric Food Chem. 1999:47:1247-53

49. Muñoz O, Diaz OP, Leyton I, Nuñez N, Devesa V, Súñer MA, et al. Vegetables collected in the cultivated Andean area of Northern Chile: Total and inorganic arsenic contents in raw vegetables. J Agric Food Chem. 2002;50:642-7.
50. McBride MB. Arsenic and lead uptake by vegetable crops grown on historically contaminated orchard soils. Appl Environ Soil Sci. 2013;2013(283472):8.

51. Jarosz Z. The effect of silicon application and type of medium on yielding and chemical composition of tomato. Acta Sci Pol Hortorum Cultus. 2014 13:171-83.

52. Kleiber T, Calomme M, Borowiak K. The effect of choline-stabilized orthosilicic acid on microelements and silicon concentration, photosynthesis activity and yield of tomato grown under Mn stress. Plant Physiol Biochem. 2015;96:180-8.

53. Wang Y, Wang W, Cai J, Zhang Y, Qin G, Tian S. Tomato nuclear proteome reveals the involvement of specific E2 ubiquitin-conjugating enzymes in fruit ripening. Genome Biol. 2014;15:1-19.

54. Nguyen Q-TT, Huang T-L, Huang H-J. Identification of genes related to arsenic detoxification in rice roots using microarray analysis. Int J Biosci Biochem Bioinforma. 2014:4:22-7.

55. Chen L, Song Y, Li S, Zhang L, Zou C, Yu D. The role of WRKY transcription factors in plant abiotic stresses. Biochim Biophys Acta - Gene Regul Mech. 2012;1819:120-8.

56. van Bockhaven J, de Vleesschauwer D, Hofte M. Towards establishing broad spectrum disease resistance in plants: silicon leads the way. J Exp Bot. 2012; 64:1281-93.

57. Singh VK, Upadhyay RS. Effects of arsenic on reactive oxygen species and antioxidant defense system in tomato plants. Toxicol Environ Chem. 2014; 96:1374-83.

58. Zhou ML, Yang XB, Zhang Q, Zhou M, Zhao EZ, Tang YX, et al. Induction of annexin by heavy metals and jasmonic acid in Zea mays. Funct Integr Genomics. 2013;13:241-51.

59. Stone SL. The role of ubiquitin and the $26 \mathrm{~S}$ proteasome in plant abiotic stress signaling. Front Plant Sci. 2014;5:135.

60. Kurepa J, Toh-E A, Smalle JA. 265 proteasome regulatory particle mutants have increased oxidative stress tolerance. Plant J. 2008;53:102-14.

61. Sung D, Kim T, Komives EA, Mendoza-cózatl DG, Schroeder JI. ARS5 is a component of the $26 \mathrm{~S}$ proteasome complex, and negatively regulates thiol biosynthesis and arsenic tolerance in Arabidopsis. Plant J. 2009;59(5):802-13.

62. Pan X, Zhu B, Zhu H, Chen Y, Tian H, Luo Y, et al. iTRAQ protein profile analysis of tomato green-ripeMutant reveals new aspects critical for fruit ripening. J Proteome Res. 2014;13:1979-93.

63. Sengupta D, Naik D, Reddy AR. Plant aldo-keto reductases (AKRs) as multitasking soldiers involved in diverse plant metabolic processes and stress defense: a structure-function update. J Plant Physiol. 2015;179:40-55.

64. Ioannidi E, Kalamaki MS, Engineer C, Pateraki I, Alexandrou D, Mellidou I, et al. Expression profiling of ascorbic acid-related genes during tomato fruit development and ripening and in response to stress conditions. J Exp Bot. 2009;60:663-78.

65. Simpson PJ, Tantitadapitak C, Reed AM, Mather OC, Bunce CM, White SA, et al. Characterization of two novel Aldo-Keto Reductases from Arabidopsis: expression patterns, broad substrate specificity, and an open active-site structure suggest a role in toxicant metabolism following stress. J Mol Biol. 2009;392:465-80.

66. Chakrabarty D, Trivedi PK, Misra P, Tiwari M, Shri M, Shukla D, et al. Comparative transcriptome analysis of arsenate and arsenite stresses in rice seedlings. Chemosphere. 2009;74:688-702.

67. Guerriero G, Hausman J-F, Legay S. Silicon and the plant extracellular matrix. Front Plant Sci. 2016:7:1-9.

68. He Y, Wu J, Lv B, Li J, Gao Z, Xu W, et al. Involvement of 14-3-3 protein GRF9 in root growth and response under polyethylene glycol-induced water stress. J Exp Bot. 2015;66:2271-81.

69. Exley C. A possible mechanism of biological silicification in plants. Front Plant Sci. 2015:6:853.

70. Goulao LF, Oliveira CM. Cell wall modifications during fruit ripening: when a fruit is not the fruit. Trends Food Sci Technol. 2008:19:4-25.

71. Schröder R, Wegrzyn TF, Sharma NN, Atkinson RG. LeMAN4 endo- $\beta$ mannanase from ripe tomato fruit can act as a mannan transglycosylase or hydrolase. Planta. 2006;224:1091-102.

72. Ruiz-May E, Rose JK. Progress toward the tomato fruit cell wall proteome. Front Plant Sci. 2013:4:159.

73. Duquesnoy I, Goupil P, Nadaud I, Branlard G, Piquet-Pissaloux A, Ledoigt G. Identification of Agrostis tenuis leaf proteins in response to $\mathrm{As}(\mathrm{V})$ and $\mathrm{As}(\mathrm{III})$ induced stress using a proteomics approach. Plant Sci. 2009:176:206-13.

74. Zhang Y, Wang C, Lin Q, Gao F, Ma Y, Zhang M, et al. Genome-wide analysis of phylogeny, expression profile and sub-cellular localization of SKP1-like genes in wild tomato. Plant Sci. 2015;238:105-14. 
75. Paulose B, Kandasamy S, Dhankher OP. Expression profiling of Crambe abyssinica under arsenate stress identifies genes and gene networks involved in arsenic metabolism and detoxification. BMC Plant Biol. 2010;10:108.

76. Howe GA, Schilmiller AL. Oxylipin metabolism in response to stress. Curr Opin Plant Biol. 2002;5:230-6.

77. Nishimura K, van Wijk KJ. Organization, function and substrates of the essential Clp protease system in plastids. Biochim Biophys Acta. 2015;1847:915-30.

78. Komatsu A, Moriguchi T, Koyama K, Omura M, Akihama T. Analysis of sucrose synthase genes in citrus suggests different roles and phylogenetic relationships. J Exp Bot. 2002;53:61-71.

79. Hirschmann F, Krause F, Papenbrock J. The multi-protein family of sulfotransferases in plants: composition, occurrence, substrate specificity, and functions. Front Plant Sci. 2014:5:556.

80. Hong Yu T, Yang Peng Y, Xia Lin C, Hao Qin J, Shou LH. Application of iron and silicon fertilizers reduces arsenic accumulation by two Ipomoed aquatica varities. J Integr Agric. 2016;15:2613-9.

81. Barsan C, Sanchez-Bel P, Rombaldi C, Egea I, Rossignol M, Kuntz M, et al. Characteristics of the tomato chromoplast revealed by proteomic analysis. J Exp Bot. 2010;61:2413-31.

82. Mitani-Ueno N, Yamaji N, Zhao FJ, Ma JF. The aromatic/arginine selectivity filter of NIP aquaporins plays a critical role in substrate selectivity for silicon, boron, and arsenic. J Exp Bot. 2011:62:4391-8.

Submit your next manuscript to BioMed Central and we will help you at every step:

- We accept pre-submission inquiries

- Our selector tool helps you to find the most relevant journal

- We provide round the clock customer support

- Convenient online submission

- Thorough peer review

- Inclusion in PubMed and all major indexing services

- Maximum visibility for your research

Submit your manuscript at www.biomedcentral.com/submit
Biomed Central 